\title{
医療ビッグデータを用いた医薬品の安全性，有効性のエビデンス構築と臨床応用
}

\author{
百＼cjkstart賢二, ${ }^{*}, a$ 安 武夫, ${ }^{b}$ 佐々木忠徳 $c$
}

\section{Development and Application for Drug-safety and Efficacy Using a Large Claims Data}

\author{
Kenji Momo, ${ }^{*, a}$ Takeo Yasu, $^{b}$ and Tadanori Sasaki ${ }^{c}$ \\ ${ }^{a}$ Department of Hospital Pharmaceutics, School of Pharmacy, Showa University; 1-5-8 Hatanodai, Shinagawa-ku, \\ Tokyo 142-8555, Japan: ${ }^{b}$ Department of Medicinal Therapy Research, Pharmaceutical Education and Research \\ Center, Meiji Pharmaceutical University; 2-522-1 Noshio, Kiyose, Tokyo 204-8588, Japan: and 'Department \\ of Pharmacy, Showa University Hospital; 1-5-8 Hatanodai, Shinagawa-ku, Tokyo 142-8666, Japan.
}

(Received August 26, 2020)

\begin{abstract}
Recent years, evidences for medical safety and efficacy are accelerated-developing using medical big data. Medical big data were adequate for analyzing 1) rare events that difficult for finding in each hospital, 2) for comparison of bench marks obtained routine work between average data in large number of hospitals and specific hospital data and 3) prescription surveys etc. As so far, these analyses using medical big data were conducted by academia and/or researcher. However, in these days, evidences using medical big data were focused on hospital pharmacists little by little. In this review, we show 3 researches using large claims data such as 1) risk factors assessing for failed low-density lipoprotein level achievement in members of the working-age population, 2) prevalence of drug-drug interaction in atrial fibrillation patients and 3) assessment of "look-alike" packaging designs related to medication errors using information technology and large claims data. Medical big data such as large claims data analysis is useful and suitable for building evidences according to medical staffs-needs.
\end{abstract}

Key words — medical big data; claims data; pharmacist

\section{1. はじめに}

医療現場においては，医師，薬剤師を始めとする メディカルスタッフが日々の診療等を行い，その内 容を診療録へ記録している. 例えば，メディカルス タッフが「臨床的な問い」を想起し，過去の診療録 から情報を集めて，研究としてまとめようとしたと する，その研究はうまくいくだろうか．当然，「問 い」の内容によって，うまくいく場合と，うまくい かない場合がある，後者の場合，例えば類似の背 景，情報を有した患者を，解析に足りるほど集める ことができないことなどに代表される，後方視的研 究の限界点にぶつかることも少なくない，筆者を含 め, 特に薬剂師が実施する後方視的研究において

\footnotetext{
$a$ 昭和大学薬学部病院薬剤学講座（干142-8555 東京都 品川区旗の台 1-5-8), $b$ 明治薬科大学（下204-8588 東 京都清瀬市野塩 2-522-1), ${ }^{\circ}$ 昭和大学病院薬剂部 (厂142-8666 東京都品川区旗の台 1-5-8)

*e-mail: momokenji3@gmail.com 本総説は, 日本薬学会第 140 年会シンポジウム S45 で 発表した内容を中心に記述したものである.
}

は，多くの場合，単施設（自施設）の診療情報を用 いることが多いため, サンプルサイズの観点から悩 みが尽きないこともしばしば経験する。本稿では, 筆者が JMDC 株式会社より提供された（購入した） 医療ビッグデータを利用し，薬剤師として行ってき た研究の具体例を紹介するとともに，臨床現場にお ける医療ビッグデー夕利用の発展性について考えた い. なお，診療録より得られる情報と，医療ビッグ データより得られる情報の質的, 量的な違いなどに 関する部分は，他稿で説明されているため，割愛さ せて頂く。

2. 脂質異常症治療薬であるスタチン製剤の有効 性と安全性に関する検討1)

脂質異常症患者では，スタチン製剤の投与による LDL-C 值の適正なコントロールが重要である。過 去の報告では目標 LDL-C 值の到達率及びスタチン 製剤の中止率は世代により異なることが報告されて いる（高齢者において高到達率，低中止率)。2,3)さ らに，社会的・経済的な地位が高い患者では，それ 以外の患者と比べてスタチン製剤のアドヒアランス 

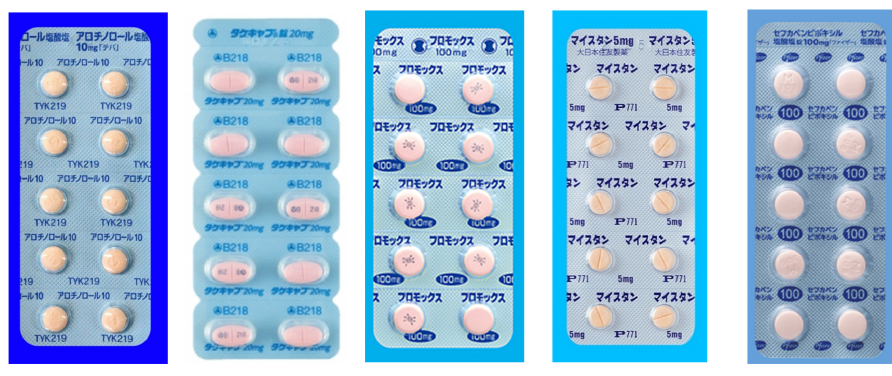

\begin{tabular}{ccccc}
\hline Sheet color & Tablet color & Sheet line color & Upper color & Character color \\
Blue & Orange & None & Blue & Blue \\
\hline
\end{tabular}

Fig. 1. Examples of Five Design Elements Used to Match Look-alike Drug Packaging (Color figure can be accessed in the online version.)

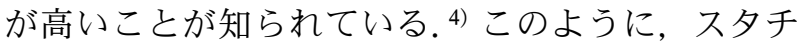
ン製剤による治療は，患者の背景により大きく異な り，薬剤師による服薬指導等における係わり方も患 者個々に合わせる必要がある.

そこで，本研究では，特にリスクの高いと考えら れる，二次予防を目的としてスタチン製剤と抗血小 板薬の併用投与を受けている働き盛りの患者を対象 とし， LDL-C の目標值（100 mg/dL 未満）未到達 患者における影響因子を探索した。

具体的には, 社会保険加入者における健康診断情 報を有する患者 201226 名から，低用量アスピリン とスタチン製剤を新規に開始した患者のうち，60 歳以下の男性 294 名に関して 3 年間観察した。 その 結果，対象患者における目標 LDL-C 值到達率は $50 \%$ 程度であること, さらに目標 LDL-C 值未到達 に及ぼす影響因子としては，低用量アスピリン及び スタチン製剤併用前の LDL-C 值が高い患者，スタ チン製剤のアドヒアランスが低い患者において目標 LDL-C 值を到達しづらいということを明らかにし ている.

本研究では，心血管イベント発生時における社会 的な影響の大きい，働き盛りの男性を対象とするこ とにより，上述の LDC-C 值の目標未到達患者の特 徵を明らかにし, 臨床の薬剤師による服薬指導等に おける具体的な介入ポイントを示すことに成功した 例である.

\section{3. 心房細動患者における薬物相互作用の発症実} 態調査5)

薬物相互作用が知られる組み合わせを含む薬物治 療が行われている患者は，入院患者の $19 \%$ ，外来

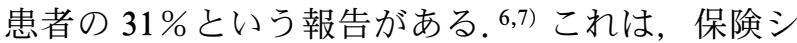
ステムの違い，人種の違いなどもあると想定され， 一概に日本人にあてはまるとは言いづらいものの, 一般に臨床的に問題となる薬物相互作用の発症頻度 はそれほど高くない，そのため，医療機関それぞれ における調査のみでは実態の把握が難しく，また相 互作用に起因する有害事象の発現率に至っては情報 の収集が困難である。そこで本研究では，抗凝固薬 による治療を開始した心房細動患者を対象とし，

Pharmaceuticals and Medical Devices Agency (PMDA) が実施している有害事象自発報告システ ム (Japanese Adverse Drug Event Report database; JADER）を用い，報告頻度の高い薬物相互作用を 抽出するとともに，レセプトデータを用い，当該組 み合わせの実態調查として, 併用頻度及び併用後の 出血の有害事象の発現頻度を調査した.

具体的には，JADER より入手した薬物相互作用 の発症例として，1910名の中から，抗凝固薬に関 連した薬物相互作用であり，かつ報告頻度が 4 件以 上の薬物相互作用の組夕合わせを抽出した。これに 加えて, 種々文献より臨床的に注意が必要な薬物相 互作用の組み合わせ 144 種類を，「特に臨床上問題 となり得る薬物相互作用」と定義した。これらの組 み合わせのリアルワールドにおける併用頻度と, 併 用後の出血の有害事象発症の頻度の調査を行うこと を目的として，心房細動患者 3290 名のレセプト データを用いて検討を行つた。 その結果，抗凝固薬 の投与から 3 力月間の追跡期間の間に， $26.7 \%$ （879 名）が上述の臨床上問題となる薬物相互作用 の組み合わせで投与を受けていた。これらの患者 
を，薬物相互作用のメカニズムとして，「薬物動態 学的」及び「薬力学的」な組み合わせに分類すると, 薬物動態学的な相互作用では $8.6 \%$ の患者が, 薬力 学的では 9.2\%, 両方のメカニズムの薬物相互作用 が存在している場合には $26.3 \%$ の患者で観察期間 中の出血が認められていた。これは薬物相互作用の 組夕合わせのない薬物治療を受けていた患者におけ る出血の頻度である $4.9 \%$ と比べて高いものであっ た.

本研究では，特に抗凝固薬を介する薬物相互作用 が報告されている組み合わせで併用投与を受けてい る例においては，出血の頻度が高くなること，さら に複数のメカニズム（薬物動態学的，薬力学的）の 相互作用が存在する場合には出血の頻度が高まるた め，十分な注意が必要であることを明らかにできた ものである.

\section{4. 医薬品外観類似データベースの構築と実臨床} における外観類似薬の併用処方実態8)

本研究では, 調剤時の取り違いなどのエラーの要 因の 1 つとして知られている外観類似に着目し，特 に錠剤シートに関し，データベースを作成するとと もに，その有用性について評価した。

外観類似データベースは， Microsoft Access 2016 を用いて作成した，錠剂シートの外観写真は，製薬 企業のホームページから入手できた 2750 品目とし た。データベースの有用性評価として，がん患者の レセプトデータを利用し，無作為に抽出した 1000 処方を用い，同一処方内における外観一致率を評価 した.

データベースでは，外観類似に関し，錠剤シート の色調を 5 種類のパラメータで設定した。 具体的に は,「ヒートの色」,「錠剤の色」,「横縞」,「ヒート の耳の色」「「ヒートの耳の文字色」とした。例えば, 「ヒートの色：青」,「錠剤の色：オレンジ」,「横縞 : なし」,「ヒートの耳の色：青」，「ヒートの耳の文字 色：青」とした場合，5種類の医薬品が抽出される (Fig. 1)，レセプトデータより入手した処方情報を 利用し，外観類似データベースを用いて外観一致率 を評価したところ，5種類のパラメータが一致した 組み合わせが同一の処方内にみられる割合は，全体 の $5.9 \% ， 4$ 項目で $12.3 \%$ であった.

本研究では，錠剤の外観類似を効率的に抽出する データベースを構築し，本データベースを利用する
ことで, 調剂エラーの可能性のある外観類似薬のリ ストアップ等に利用できる可能性が考えられた。

\section{5. おわりに}

本稿では, 臨床における医療ビッグデー夕の研究 利用に関して，筆者のこれまでの経験に基づき 3 件 の研究について紹介した。いずれの研究も単施設の みの医療情報を利用した研究では実施が困難な内容 であり，得られた研究成果は実臨床へフィードバッ ク可能な情報であると感じている.

最後になるが，医療ビッグデー夕も万能ではな く，研究を開始する際には注意点も存在する。すな わち，情報量が膨大であるため，一般的なコン ピュータやソフトウェアでは処理できないという点 である．また，医療ビッグデータの入手自体に費用 がかかるものがあること，データのハンドリングに は相応の技術が必要であること，などもポイントと なろう。

医療ビッグデータを利用した研究の実施には，特 に研究費の面で苦労することも少なくないものの, 数万人，数十万人規模の医療情報を解析すること は, 将来の医学の発展に大きく寄与でき, 研究者・ 臨床家としてのモチベーションも高まるものと考え る.

将来，医療現場の臨床家の研究遂行のためのツー ルの選択肢の 1 つとして医療ビッグデータの利用が 進むことを期待したい.

利益相反＼cjkstart開示すべき利益相反はない.

\section{REFERENCES}

1) Momo K., Yasu T., Yasui H., Kuroda S., $J$. Clin. Pharm. Ther., 44, 715-719 (2019).

2) Halava H., Huupponen R., Pentti J., Kivimäki M., Vahtera J., J. Clin. Lipidol., 10, 987-995 (2016) .

3) Chi M. D., Vansomphone S. S., Liu I. L., Cheetham C., Green K. R., Scott R. D., Reynolds K., Am. J. Manage. Care, 20, e105-e112 (2014).

4) Aarnio E., Martikainen J., Winn A. N., Huupponen R., Vahtera J., Korhonen M. J., Circ. Cardiovasc. Qual. Outcomes, 9, 704-713 (2016).

5) Momo K., Kobayashi H., Sugiura Y., Yasu 
T., Koinuma M., PLoS One, 14, e0225297 (2019).

6) Reimche L., Forster A. J., van Walraven C., J. Clin. Pharmacol., 51, 1043-1050 (2011).

7) Bergendal L., Friberg A, Schaffrath A.,
Sweden. Pharm. World Sci., 17, 152-157 (1995).

8) Momo K., Shimano M., Kanezaki Y., Minagawa A., Takagi A., Seino T., Koinuma M., Pharmazie, 74, 310-312 (2019). 